\title{
Paul Kruger en Cecil Rhodes.
}

As Paul Kruger 'n galery moes gehad het, behang met die portrette van belangrike manne wie se weë syne gekruis het, sou daar aangetref word 'n bonte versameling bestaande uit gekroonde hoofde van Europese state, goewerneurs, staatsmanne, hoë amptenare en groot leiers op elke terrein vanaf Bismarck tot Ferdinand de Lesseps. Opvallend naas 'n groot a:antal Britse Lords en Sirs sou daar een gewone man sonder 'n handvatsel aan sy naam wees-Cecil John Rhodes-die 
Engelsman met die grootste visie wat Kruger se strewe sou verongeluk. Soos oor Napoleon kan baie geskiedskrywers nou nog nie uitgepraat raak oor hierdie merkwaardige verskynsel van die laaste kwart van die 19de eeu nie.

Vir nasionaalbewuste Afrikaners is die naam Rhodes byna weersinwekkend, die oorsaak van die ongeluk waarin die Afrikanervolk eenmaal gedompel was, die byna legendariese teenvoeter van Paul Kruger. Maar Rhodes was meer as dit. Hy was nie net afbreker van republikeinse apartheid in Suid-Afrika nie, hy was ook bouer van 'n staatkundig verenigde Suid-Afrika. Miskien sal die groot historiese rol wat hy gespeel het eers deur die historicus van die toekoms na waarde geskat kan word. Daar is iets in die persoon van Rhodes wat mens interesseer en boei, iets byna aantrekliks in sy brute onbeskaamdheid. Veel kan geskryf word oor die skerp teenstelling tussen hom en sy groot teenstander, die twee hooffigure op die Suid-Afrikaanse toneel gedurende die laaste twintig jaar van die vorige eeu, maar in hierdie artikel wil ons volstaan met enkele verwysing na die punte van aanraking tussen hulle en die gevolge daarvan. Albei was groot en albei werp 'n skaduwee wat tot in ons tyd strek.

Soos Paul Kruger kan Rhodes 'n idealis genoem word, maar 'n uiters nugtere, praktiese idealis, 'n sakeman vol denkbeelde en drome. Die besit van politieke mag en wêreldse rykdom, wat hy so baie begeer het, was vir hom slegs middele tot 'n doel. Sy kop was in die wolke maar sy voete vas op die aarde.

Rhodes het reeds vroeg al besef dat die hoogste ideale slegs verwesenlik kon word as die middele daartoe voorhande was en daardie middele was onbeperkte finansiële hulpbronne gepaard met politieke mag en invloed. Sy lewensideaal was om vir die Britse Ryk „Lebensraum" in Afrika te verwerf en om die kaart van Afrika, veral suidelik en sentraal-Afrika, rooi te verf. Daar moes 'n verenigde Suid-Afrika onder die Britse vlag tot stand kom. Volgens hom het Suid-Afrika voor die keuse tussen drie weë gestaan: direkte imperiale ekspansie, gedirigeer vanuit Londen; Kaapkolonie ekspansie; en republikeinse uitbreiding. Hy het die middeweg as die enigste moontlikheid gesien. SuidAfrika moes verenig en Britse gesag uitgebrei word deur middel van 'n natuurlik, hoewel geforseerde, groei van die Kaapkolonie in noordelike rigting.

Rhodes was dus 'n man met vergesigte, 'n buitegewone verskynsel 
vir sy tyd, iets unieks in die saai politieke lewe van die Kaap. Hy het geglo dat Paul Kruger, net soos hy, grootse politieke en staatkundige doelwitte nagestreef het, dat Kruger van plan was om die republiek aan die hoof wararvan hy gestaan het, so uit te brei dat dit dwarsoor Afrika gestrek het, vanaf Walvisbaai in die weste tot Delagoabaai in die ooste. Hy het gemeen om in Kruger ' $n$ geesgenoot te ervaar en herhaaldelik uitdrukkinge gegee aan sy gevoel van bewondering vir 'n man wat "sonder 'n sikspens in sy sak" sulke grootse planne kon ontwerp. Volgens Rhodes was Kruger groot in sy eenvoud en eenvoudig in sy grootheid. Volgens hom was die Transvaalse President net so vol grandiose uitbreidingskemas as hyself, iemand wat teenoor die Britse imperialisme 'n soort Boere-imperialisme wou stel. Paul Kruger was vir Rhodes sy „alter ego", sy dubbelganger.

Rhodes het natuurlik totaal mis gehad. Wel het Kruger by geleentheid verwys na 'n verenigde Suid-Afrika, natuurlik onder eie vlag, maar hy was veels te 'n nugtere en praktiese staatsman om die onmoontlike na te streef, afgesien van die feit dat die verwesenliking van 'n Boere-Empaaier geheel en al buite die vermoë en kragte van die Transvaalse Republiek was. 'n Paul Kruger met sulke denkbeelde was bloot 'n skepping van Rhodes se fantasie.

Maar tog het die Boere-President die verwesenliking van Rhodes se planne in die weg gestaan, bloot omdat dit die hoeksteen van sy beleid was om die onafhanklikheid van die Suid-Afrikaanse Republiek te bewaar. Die vryheid en onafhanklikheid is, volgens Kruger, deur God aan sy volk geskenk en dit moes as 'n kosbare kleinood gehandhaaf word, veral teen die aanslae van Rhodes en sy trawante.

Gedurende die eerste paar jaar na die Eerste Vryheidsoorlog het die Suid-Afrikaanse Republiek wel gebiedsuitbreiding weswaarts in die rigting van Bechuanaland en ooswaarts-na Zululand nagestreef, maar dit was nie ter wille van politieke magsverkryging nie. Boere-ekspansie destyds en later noordwaarts oor die Limpopo was veeleer 'n natuurlike poging om woonplek en plase te verkry vir jong Transvaalse Boere wat ' $n$ beter toekoms gesoek het. Paul Kruger het in hierdie verband teenoor sy volk gestaan soos 'n vader teenoor sy seuns vir wie hy voorsiening wou makk. Origens moet. sodanige uitbreiding gesien word as slegs poginge om die vryheid en veiligheid van Transvaal te verseker.

Rhodes as 'n tipe en 'n verskynsel was vir Kruger wesensvreemd. Terwyl die staatkunde van die Transvaalse Republiek op die voorskrifte 
van die Heilige Skrif gebaseer was, dikwels met 'n Ou-Testamentiese inslag, het vir Rhodes en sy mede-stryders die Bybel nie gegeld nie. By geleentheid het Rhodes se vriend, Jameson, self verklaar: „Die Tien Gebooie is uitgedien" en ook "godsdiens het met politiek niks te doen nie". Kruger was 'n man van die kerk, in die wêreld. Rhodes 'n man van die wêreld, in die wêreld. Sy norm was: niks is so suksesvol as sukses nie. Soos Napoleon het hy gemeen dat God aan die kant van die sterkste bataljons veg. Kruger was in sy siel oortuig dat geregtigheid 'n volk verhoog en dat God die swakke en verdrukte nooit sou verlaat nie.

Paul Kruger en Cecil Rhodes het meer as bloot teenoorgestelde politieke beskouings verteenwoordig. Hulle het twee lewensbeskouings beliggaam, diametraal teenoor mekaar gestel. Botsing tussen hulle op staatkundige gebied was noodwendig omdat hulle al twee in 'n posisie was om krag by hulle menings te sit: Kruger as president van 'n republiek en Rhodes as Eerste Minister van 'n kolonie. Oënskynlik het die stryd gegaan oor gebiedsuitbreiding en politieke hegemonie, in werklikheid oor die toekoms van Suid-Afrika en die siel van die volk.

Drie maal in die loop van tien jaar vanaf 1885 tot 1894 het die twee manne mekaar van aangesig tot aangesig bejeen. Drie maal het hulle oor belangrike strydpunte persoonlik gebots. By nie een geleentheid is baie woorde gespreek nie, maar elke keer het al twee besef dat dit om fundamentele dinge gaan.

Die eerste ontmoeting het plaasgevind by Veertienstrome in Januarie 1885. Ö̈nskynlik was Rhodes vriendelik en tegemoetkomend, maar hy het by hierdie geleentheid daarin geslaag om enige Transvaalse gebiedsujtbreiding in Bechuanaland te verhinder. Hy het daardeur vir die Kaapkolonie die beheer gekry oor die weg na die noorde, na die land van Lobengula, die latere Rhodesië. Dit was die eerste stap ter uitvoering van sy beleid van noordwaartse ekspansie en die verkryging van die beheer oor die binnelande van suidelik Afrika. Rhodes het die eerste ronde gewen.

Hulle tweede ontmoeting het plaasgevind in November 1890 in Pretoria. Hierdie keer was Rhodes se planne om die gebied tussen die Limpopo en die Sambesi in te palm, reeds ver gevorder. Hy moes nog seker maak dat Paul Kruger en sy mense hulle hande daar tuis hou. Rhodes is met alle eerbewyse in die republikeinse hoofstad onthaal en die President het hom, oudergewoonte, op die stoep van die residensie 
ontvang. Rhodes het sy gewone taktiek probeer toepas om sy teenstander te ,square" (om te koop), want hy het gemeen dat elke man "sy prys" het. Hierdie keer het hy die aanloklike ,aanbod" van Delagoabaai in die vooruitsig gestel in ruil vir die versekering dat die republiek afsien van enige uitbreidingsplanne noord van de Limpopo. En hierdie prys sou nie deur hom nie maar deur die vreedsame Portugese bure betaal word. „Transvaal het 'n seehawe nodig. U moet Delagoabaai kry, dit desnoods vat", het hy gesê. Die antwoord was 'n dik rookwolk uit die pyp van die President en 'n subiete weiering om andermensgoed te vat, 'n daad van diefstal en geweld waarop slegs 'n vloek kan rus. Die verkryging van 'n hawe aan die ooskus ten einde die republiek van 'n lewensaar te voorsien, was die lieflingsdroom van die President. Maar ten koste van die verkragting van sy gewete? Die prys was te hoog. Omstandighede het later 'n einde gemaak aan enige noordwaartse uitbreidingsplanne van die republiek, veral toe die Britse regering vreedsame verkeersontwikkeling van die republiek in die rigting van die see deur Swasiland in die vooruitsig gestel het. Wat die noorde betref, het Rhodes die tweede ronde gewen, maar die President het sy siel bewaar.

Die derde ontmoeting het plaasgevind in 1894 toe Rhodes reeds al daarin geslaag het om Transvaal binne sy bestaande grenslyne vas te pen. Die volgende stap was die absorbering van die republiek self. Dit moes ingesluk word deur die Kaapkolonie deur middel van 'n tolunie, 'n tariewe-ooreenkoms, ooreenkomste insake poswese, muntwese, naturellebeleid en selfs die gemene reg. Op vreedsame wyse sou aldus die einde van republikeinse onafhanklikheid voorberei word. As Rhodes net die koppige ou man kon oorhall! Maar Kruger het agter al sy planne die hand van die imperialis gesien wat sy volk 'n plek onder die son van Suid-Afrika ontsê het. Hy het geweier om selfs 'n kompromis te aanvaar.

Na tien jaar van oorreding, chicanerie, omkopery en bedrog het Rhodes nog steeds vasgekyk teen die muur van presidensiële hardnekkigheid. Wat makeer die man? „Ek kry hom jammer”, het Rhodes gesê. Sy geduld was nou op die end. Hy het haastig geword en gereed gemaak om sy laaste troefkaart te speel.

Die ontwikkelende goudmynbedryf en die aanwesigheid van duisende Uitlanders in Transvaal moes gebruik word om Kruger en sy Boererepubliek na sy wil te buig. $N o g$ in 1895 het hy 'n geskil aangaande 
spoorwegtariewe probeer uitbuit om die republiek en Engeland in oorlog te dompel. Hy het byna in sy doel geslaag, maar die President was te verstandig en het deur betyds toe te gee, die poging verydel.

Rhodes het opgehou om 'n staatsman te wees. Hy het alle verantwoordelikheidsgevoel verloor en van nou af 'n roekelose, waaghalsige avonturier geword. Sy gang is nie meer bestuur deur oorleg nie, maar deur 'n politieke dobbelgees. Geweld was al wat oorgebly het. Die uitkoms was die komedie van die Jameson-inval en die tragedie van die tweede Vryheidsoorlog.

Die persoonlike konflikt tussen Kruger en Rhodes was noodwendig en begryplik, die militêre konflikt tussen Brittanje en die republieke was onnodig en dit het tragiese gevolge gehad. Die ,edele”, „regverdige" Engeland waaraan Kruger geglo het, is deur Rhodes gekorrupteer. Engeland met sy non-konformiste gewete en sy eerbiedwaardige en gelowige vorstin wat geweier het om haar deur wêreldse dinge te laat amuseer, het sy gewete verkrag en sy Suid-Afrikaanse beleid op die groot leuen begin baseer. Die Engelse volk het geglo dat vernietiging van 'n ,korrupte Kruger-oligargie" en vernietiging van die republiek 'n gode-welgevallige taak was. Die Tweede Vryheidsoorlog het aldus ' $n$ moderne kruistog geword. „Deus vult!"

Die tragedie van die Afrikaanse volk was ook die persoonlike tragedie van Paul Kruger: 'n verlore oorlog, ballingskap en uiteinde in die vreemde. Kruger het die ondergang van sy republiek en met hom die Vrystaat wat trou aan sy verbondsverpligtinge, dieselfde weg opgegaan het, nie lank oorleef nie. . Hy het berustend sy oumanshand op die Bybel geplaas en nooit sy geloof in die herlewing van sy volk prysgegee nie. Die venster van sy sterfkamer het na die suide gekyk, na Afrika waar God sy werk nog moes voleindig, waar God sy volk nie sou verlaat nie, waar die einde van die werk wat Kruger in God begin het, ,goed sou wees."

Rhodes is ocrlede ter'wyl die brand wat hy gestig het, nog nie geblus was nie. Hy, die man van die ruimtes en die vergesigte, het op sy sterfbed gesmag na asem in 'n beknopte huisie in Muizenberg aan die see.

Binne 'n dekade na die dood van die twee groot teenstanders is die Unie van Suid-Afrika op die ruïnes van die verlede gebore. Die Britse vlag het gewapper van Tafelbaai tot Sambesi. Rhodes se ideaal is verwesenlik. Maar het hy geseëvier? Gedurende die halwe eeu wat gevolg 
het op die vrede van Vereeniging, het Boere-generaals, getoë in die skool van Kruger, die politieke leiding van die lotgevalle van Suid-Afrika in hande gehou. . Die Afrikaanse volk het nie verdwyn nie, maar gedy, want uit die as van Vereeniging het 'n nuwe geslag opgestaan wat die stryd van vryheid op 'n ander terrein voortgesit het. Vir die nuwe geslag het die trots op die verlede die hoeksteen van die geloof in die toekoms geword. Na uitwendige vorm was die Unie van Suid-Afrika Brits, na geestelike inhoud het dit Afrikaans geword. Die skok wat twee vallende woudreuse gemaak het, het 'n merkwaardige naklank veroorsaak. Mens hoor nog die eggo's.

Die weë van God in die geskiedenis is ondeurgrondelik. Hy gebruik mense wat meen dat hulle hulle eie weg bewandel, hulle eie doelwitte nastreef. Maar hulle is ook instrumente wat per slot van rekening gelei word waarheen hulle nie wil nie. Kruger en Rhodes is op hulle tyd geroep en gebruik: Rhodes om die balkanisering van Suid-Afrika te beëindig en staatkundige eenheid selfs deur onheilige middele af te dwing; Kruger om die Afrikaanse volk van sy plek daarin te verseker en om die diepere inhoud daarvan tot 'n groot mate te bepaal.

Die skyn en die werklikheid, die skadu en die substansie, wie kan tussen hulle onderskei?

D. W. KRUGER. 